\title{
Postharvest Application of the Yeast Cryptococcus laurentii Reduces Apple Rots
}

\author{
L.E.B. Blum \\ Universidade de Brasília \\ Dept. Fitopatologia \\ Brasília, DF \\ Brazil
}

\author{
C.V.T. Amarante \\ CAV/UDESC, CP 281 \\ Dept. Fitotecnia \\ Lages, SC \\ Brazil
}

\author{
R.M. Valdebenito-Sanhueza \\ EMBRAPA Uva e Vinho \\ Bento Gonçalves, RS \\ Brazil
}

Keywords: Glomerella cingulata, Malus domestica, Penicillium expansum, Pezicula malicorticis

\begin{abstract}
Rots might be responsible for substantial post-harvest losses on apples (Malus domestica). The blue mold caused by Penicillium expansum, the bitter rot caused by Glomerella cingulata and the 'bull's-eye rot' induced by Pezicula malicorticis are among the most common rots. Great attention has been given to less environmental damaging alternatives for the control of post-harvest diseases. The post-harvest application of yeasts, such as Cryptococcus laurentii, is one of the options to control fruit rots. This study was carried out to test the efficiency of $C$. laurentii on fruit rots control in 'Fuji' and 'Gala' apples. After application of treatments by immersion, the fruits were stored in laboratory $\left(15-20^{\circ} \mathrm{C}\right.$ and $\left.60-70 \% \mathrm{RH}\right)$ or in cold storage $\left(1^{\circ} \mathrm{C}\right.$ and $\left.90-95 \% \mathrm{RH}\right)$. The pathogens were applied at the concentration of $10^{2}$ conidia $\mathrm{mL}^{-1}$, the yeast at $10^{7}$ cells $\mathrm{mL}^{-1}$ and the fungicides at $150 \mathrm{mg} \mathrm{l}^{-1}$. An isolate (36) of $C$. laurentii was as efficient as the fungicides (thiabendazole and iprodione) to reduce apple fruit rots $(G$. cingulata, $P$. expansum, and $P$. malicorticis). In cold storage trials, $C$. laurentii was as efficient as the fungicides (thiabendazole, iprodione, chlorhexidine digluconate, sodium dichloro-s-triazinetrione, sodium dicloroisocyanurate and sodium hypochlorite) to reduce $P$. expansum fruit rot. The application of $C$. laurentii did not affect flesh firmness and total soluble solids content of the fruits.
\end{abstract}

\section{INTRODUCTION}

In Brazil, apple (Malus domestica Borkh.) is mainly cultivated in Santa Catarina state. In the years 2001-2002 this state produced around 400,000 metric tons of 'Gala' and 'Fuji' apples (ABPM, 2002). Nevertheless, during storage and commercialization substantial losses of apples are due to post-harvest rots. Among the most important rots there are those caused by Glomerella cingulata (Stonem) Spauld. \& Schrenk ('Bitter rot'), Penicillium expansum Link. ('Blue mold') and Pezicula malicorticis (H. Jacks.) Nannf. ('Bull's eye rot') (Boneti et al., 1999; Blum et al., 2000).

The control of apple post-harvest diseases is generally performed by dipping fruits in fungicide suspensions. However, a reduction of fungicide application on fruits and vegetables is a worldwide concern. The biological control of some fruit diseases with antagonists, such as yeasts , has shown promising results (Janisiewicz and Roitman, 1998; Valdebenito-Sanhueza and Cattanio, 2001). Additionally, the use of biocontrol agents has contributed to reduce fungicide residues on fruits.

Considering the benefits and the potential for biocontrol of fruit diseases with antagonist yeasts, this study was conducted to evaluate the efficacy of Cryptococcus laurentii (Kufferath) Skinner to control bitter rot, blue mold and bull's eye rot on 'Gala' and 'Fuji' apples.

\section{MATERIALS AND METHODS}

The inoculum of $P$. expansum, $G$. cingulata and $P$. malicorticis was produced growing these fungi on PDA $\left(20^{\circ} \mathrm{C}\right)$ for 7,10 and 14 days, respectively. C. laurentii (isolate 36), selected by Valdebenito-Sanhueza and Cattanio (2001), was also grown for 
$72 \mathrm{~h}$ on PDA.

The experimental treatments for the laboratory tests are shown in Table 1. These experiments were arranged in a complete randomized block design with eight replications of 20 fruits each. Initially, fruits of 'Fuji' were surface sterilized by dipping in sodium hypochlorite (1\% of active chlorine) for three minutes and rinsed with sterile water. Then apples were needle wounded (four wounds per fruit $1 \mathrm{~cm}$ apart, with each wound size of 1 $\mathrm{mm}$ in diameter and $1 \mathrm{~mm}$ deep) nearby the middle fruit region. Afterwards, these fruits were dipped for 15 minutes in the suspensions prepared with sterilized water and contaminated with the pathogens. The inoculum's concentration for each pathogen suspension was adjusted (Neubauer chamber) to $10^{2}$ conidia $\mathrm{mL}^{-1}$. Then, in such suspensions were applied the fungicides (Table 1) or the yeast $\left(10^{7}\right.$ cells $\left.\mathrm{mL}^{-1}\right)$. After application of the products, the fruits were set on paper trails and incubated in a dark storage room $\left(20^{\circ} \mathrm{C}\right.$ and $\left.60-70 \% \mathrm{RH}\right)$. As soon as the first symptoms appeared the incidence $(\%)$ and diameter $(\mathrm{mm})$ of the lesions was daily recorded. In order to simplify data presentation only results of the evaluations made at ten days for P. expansum, at 22 days for $G$. cingulata, and at 30 days for $P$. malicorticis were reported. In each experiment a control treatment including only yeast application was included. However, the results of this treatment were not shown (Table 1) because they were not used in the statistical analyses.

Four commercial cold chamber tests (three with 'Fuji' and one with 'Gala') were performed and the products applied are presented on Table 2. The experiments were arranged in a complete block design with six replications of 20 fruits each. Fruits of 'Fuji' and 'Gala' apples in these tests were submitted to the same procedures followed in the laboratory trials. However, the suspensions were prepared in sterilized water lately contaminated with $P$. expansum $\left(10^{2}\right.$ conidia $\left.\mathrm{mL}^{-1}\right)$. In such suspensions the fungicides (Table 2$)$ or the yeast isolate $\left(10^{7}\right.$ cells $\left.\mathrm{mL}^{-1}\right)$ were added. As in the laboratory tests a control treatment with only the yeast isolate was added, but, its results were not used for statistical analyses purposes. After the application of the products, the fruits were set on paper trials which were put on commercial paper boxes $(18 \mathrm{~kg})$, and then stored in commercial cold chamber $\left(1^{\circ} \mathrm{C}\right.$ and $\left.90-95 \% \mathrm{RH}\right)$. Following a period of 40 to 90 days of storage (Table 2), the fruits were evaluated immediately afterwards and seven days after the removal from the cold chamber. In each of these two evaluations, the disease incidence $(\%)$, the pathogen lesions diameter $(\mathrm{mm})$, the flesh firmness $\left(\mathrm{kg} \mathrm{F} \mathrm{cm}^{-2}\right)$ and the total soluble solids content $\left({ }^{\circ} \mathrm{Brix}\right)$ were recorded.

Experiments were arranged in a randomized complete block design. The data were analyzed by two-way ANOVA and differences among treatment means were evaluated for significance using Tukey's test $(\mathrm{P} \leq 0.05)$ (Forthofer and Lee, 1995). Statistical analyses were performed using the software program SigmaStat v.2 (SPSS - Jandel Scientific Software, Chicago, IL, USA).

\section{RESULTS}

Results of laboratory tests shown that treatments with $C$. laurentii were as efficient as application of fungicides (thiabendazole and iprodione) in reducing both diameter of lesions and rots incidence. The treatments with the yeast isolate significantly reduced disease when compared to the check treatment only with the pathogens (Table 1).

The data from cold chamber experiments ('Fuji') shown that $C$. laurentii, thiabendazole, iprodione, chlorhexidine digluconate, sodium dichloro-s-triazinetrione, sodium dicloroisocyanurate and sodium hypochlorite were efficient in reducing blue mold induced by $P$. expansum (Table 2 ). In the evaluations made immediately afterwards and seven days after fruit removal from cold storage the yeast isolate reduced blue mold incidence and lesions diameter (Table 2). However, in the experiment performed with 'Gala' apples, $C$. laurentii isolate significantly reduced the damages caused by $P$. expansum only in the evaluation done after fruit removal from cold chamber. In addition, it was observed that the application of $C$. laurentii did not alter any fruit desirable characteristics, such as flesh firmness and soluble solids content ( ${ }^{\circ}$ Brix) (Table 2). 


\section{DISCUSSION}

The antagonistic activity of the yeast isolate $C$. laurentii 36 used in this study can be due to its nutrient competition and hyperparasitism against the pathogens. Through these biocontrol mechanisms $C$. laurentii could reduce the activities of the pathogens and, consequently, reduce the intensity of the diseases they cause. Castoria et al. (1997) reported that $C$. laurentii (LS-28) acted against $P$. expansum and Botrytis cinerea Pers: Fr. through nutrient competition and degradation of the pathogen cell wall by its high levels of $\beta-1,3$ glucanase activities. These authors also reported that antibioses did not appear to be involved in the antagonist activity. In addition, Valdebenito-Sanhueza and Cattanio (2001) reported no in vitro antibiosis and resistance induction by isolate 36 of $C$. laurentii isolate against the blue mold pathogen tested. On tomato plants the yeast $C$. laurentii (isolate Y236) significantly reduced the disease caused by Septoria lycopersici Speg (Blum, 2000).

There are several examples of successful antagonists under laboratory conditions that fail under natural or field conditions in which environment is variable (El-Ghaouth et al., 2000; Wilson and Pusey, 1985). In this study, isolate 36 of $C$. laurentii showed to be efficient in controlling blue mold not only under laboratory, but also, under commercial storage conditions. Wilson and Pusey (1985) mentioned that the reasons of the failure in controlling diseases by some antagonists under field or commercial circumstances is the difficulty to maintain favorable environmental conditions for biocontrol agents. The constant conditions of apple storage applied in this study favoured the effectiveness of the yeast isolate used against $P$. expansum, therefore, the problems pointed out by Wilson and Pusey (1985) were not limiting.

\section{CONCLUSIONS}

Post-harvest applications of $C$. laurentii (isolate 36) reduced the intensity of rots induced by Glomerella, Penicillium and Pezicula under laboratory environment. In commercial cold chamber, $C$. laurentii was as efficient as the fungicides in controlling blue mold and did not alter fruit quality expressed by flesh firmness and soluble solids content $\left({ }^{\circ}\right.$ Brix $)$.

\section{Literature Cited}

ABPM. 2002. Associação Brasileira dos Produtores de Maçã. http://www.abpm.org.br/.

Blum, L.E.B. 2000. Reduction of incidence and severity of Septoria lycopersici leaf spot of tomato with bacteria and yeasts. Ciência Rural 30:761-765.

Blum, L.E.B., Amarante, C.V.T., Prado, G., Arioli, C.J., Guimarães, L.S. and Dezanet, A. 2000. Cultivar, método de inoculação e concentração de inóculo afetando as podridões da maçã por Penicillium expansum e Pezicula malicorticis. Fitopatologia Brasileira 25:359-360.

Boneti, J.I.S., Ribeiro, L.G. and Katsurayama, Y. 1999. Manual de identificação de doenças e pragas da macieira. EPAGRI, Florianópolis.

Castoria, R., De Curtis, F., Lima, G. and De Cicco, V. 1997. Beta-1-3-glucanase activity of two saprophytic yeasts and possible mode of action as biocontrol agents against postharvest diseases. Postharvest Biol. Technol. 12:293-300.

El-Ghaouth, A., Smilanick, J.L. and Wilson, C.L. 2000. Enhancement of the performance of Candida saitoana by the addition of glycolchitosan for the control of postharvest decay of apple and citrus fruit. Postharvest Biol. Technol. 19:103-110.

Forthofer, R.N. and Lee, E.S. 1995. Introduction to biostatistics: a guide to design, analysis and discovery. Academic Press, San Diego, California.

Janisiewicz, W.J. and Roitman, J. 1998. Biological control of Pseudomonas cepacia. Phytopathology 78:194-198.

Valdebenito-Sanhueza, R.M. and Cattanio, M.E. 2001. Controle biológico de Penicillium expansum em pós-colheita de maçãs 'Fuji'. Fitopatologia Brasileira 26: 445.

Wilson, C.L. and Pusey, P.L. 1985. Potential for biological control of postharvest plant disease. Plant Dis. 69:375-378. 


\section{$\underline{\text { Tables }}$}

Table 1. Diameter and incidence of apple ('Fuji') rots caused by Glomerella cingulata, Penicillium expansum and Pezicula malicorticis under laboratory conditions.

\begin{tabular}{|c|c|c|c|c|c|c|}
\hline \multirow{3}{*}{ Treatment } & \multicolumn{2}{|c|}{ Glomerella } & \multicolumn{2}{|c|}{ Penicillium } & \multicolumn{2}{|c|}{ Pezicula } \\
\hline & \multicolumn{6}{|c|}{ Diameter of the lesion (mm) } \\
\hline & $1^{1}$ & $2^{2}$ & $1^{1}$ & $2^{2}$ & $1^{1}$ & $2^{2}$ \\
\hline Pathogen $(\mathrm{P})^{5}$ & $7.5 \mathrm{a}^{3,4}$ & $2.3 \mathrm{a}$ & $6.2 \mathrm{a}$ & $6.0 \mathrm{a}$ & $4.9 \mathrm{a}$ & $0.6 \mathrm{a}$ \\
\hline Iprodione $^{6}+\mathrm{P}$ & $5.5 \mathrm{~b}$ & $1.1 \mathrm{bc}$ & $0.4 \mathrm{c}$ & $4.2 \mathrm{ab}$ & $1.7 \mathrm{~b}$ & $0.1 \mathrm{~b}$ \\
\hline Thiabendazole $^{6}+\mathrm{P}$ & $5.2 \mathrm{~b}$ & $1.6 \mathrm{ab}$ & $2.6 \mathrm{~b}$ & $4.4 \mathrm{ab}$ & $1.1 \mathrm{bc}$ & $0.2 \mathrm{~b}$ \\
\hline \multirow[t]{2}{*}{ Yeast $^{7}+\mathrm{P}$} & $3.0 \mathrm{c}$ & $0.2 \mathrm{c}$ & $0.1 \mathrm{c}$ & $0.1 \mathrm{c}$ & $0.6 \mathrm{c}$ & $0.1 \mathrm{~b}$ \\
\hline & \multicolumn{6}{|c|}{ Incidence of rot $(\%)$} \\
\hline Pathogen $^{5}(\mathrm{P})$ & $26.9 \mathrm{a}$ & $12.7 \mathrm{a}$ & $44.5 \mathrm{a}$ & $38.6 \mathrm{a}$ & $30.7 \mathrm{a}$ & $7.1 \mathrm{a}$ \\
\hline Iprodione $^{6}+\mathrm{P}$ & $22.6 \mathrm{ab}$ & $5.8 \mathrm{bc}$ & $4.0 \mathrm{c}$ & $26.8 \mathrm{a}$ & $12.3 \mathrm{bc}$ & $0.6 \mathrm{~b}$ \\
\hline Thiabendazole $^{6}+\mathrm{P}$ & $20.3 \mathrm{~b}$ & $8.1 \mathrm{ab}$ & $19.8 \mathrm{~b}$ & $28.3 \mathrm{a}$ & $7.1 \mathrm{~cd}$ & $2.1 \mathrm{~b}$ \\
\hline Yeast $^{7}+\mathrm{P}$ & $14.6 \mathrm{c}$ & $1.5 \mathrm{c}$ & $0.7 \mathrm{c}$ & $0.7 \mathrm{~b}$ & $3.6 \mathrm{~d}$ & $1.5 \mathrm{~b}$ \\
\hline
\end{tabular}


Table 2. Diameter of the lesions and incidence of the blue mold (Penicillium expansum), flesh firmness and total soluble solid content (TSS, ${ }^{\circ}$ Brix) of apples ('Fuji' and 'Gala'). Commercial cold chamber experiments $\left(1^{\circ} \mathrm{C} / 90-95 \% \mathrm{RH}\right)$.

\begin{tabular}{|c|c|c|c|c|c|c|c|c|}
\hline \multirow{4}{*}{ Treatment } & \multicolumn{6}{|c|}{ 'Fuji' } & \multirow{2}{*}{\multicolumn{2}{|c|}{$\begin{array}{l}\text { 'Gala' } \\
\text { Test } 4{ }^{4}\end{array}$}} \\
\hline & \multicolumn{2}{|c|}{ Test $1^{1}$} & \multicolumn{2}{|c|}{ Test $2^{2}$} & \multicolumn{2}{|c|}{ Test $3^{3}$} & & \\
\hline & $0 \mathrm{~d}^{5}$ & $7 d^{6}$ & $0 \mathrm{~d}$ & $7 \mathrm{~d}$ & $0 \mathrm{~d}$ & $7 \mathrm{~d}$ & $0 \mathrm{~d}$ & $7 \mathrm{~d}$ \\
\hline & \multicolumn{8}{|c|}{ Diameter of the lesion (mm) } \\
\hline Pathogen $^{9}$ & $1.1 \mathrm{a}^{7}$ & $6.7 \mathrm{a}$ & $0.3 \mathrm{a}$ & $4.4 \mathrm{a}$ & $6.8 \mathrm{a}$ & $16.8 \mathrm{a}$ & $0.9 \mathrm{a}$ & $4.5 \mathrm{a}$ \\
\hline Iprodione $^{10}$ & $0.1 b$ & $1.3 b$ & $0.0 \mathrm{~b}$ & $2.6 \mathrm{~b}$ & $0.7 \mathrm{~b}$ & $2.7 \mathrm{~b}$ & $0.0 \mathrm{~b}$ & $0.6 \mathrm{c}$ \\
\hline Thiabendazole $^{10}$ & $0.1 \mathrm{~b}$ & $0.6 b$ & $0.1 b$ & $1.1 \mathrm{~b}$ & $0.4 \mathrm{~b}$ & $1.2 \mathrm{bc}$ & $0.0 \mathrm{~b}$ & $0.0 \mathrm{c}$ \\
\hline Yeast $^{11}$ & $0.0 \mathrm{~b}$ & $0.6 b$ & $0.1 \mathrm{~b}$ & $1.4 \mathrm{~b}$ & $0.2 \mathrm{~b}$ & $0.8 b c$ & $0.3 b$ & $2.9 \mathrm{ab}$ \\
\hline Na dichloro-s-triazinetrione ${ }^{10}$ & $*^{8}$ & $*$ & $*$ & $*$ & $0.9 \mathrm{~b}$ & $2.2 \mathrm{bc}$ & $0.1 b$ & $0.8 \mathrm{c}$ \\
\hline Sodium hypochlorite ${ }^{10}$ & $*$ & $*$ & $*$ & $*$ & $0.0 \mathrm{~b}$ & $1.0 \mathrm{bc}$ & $0.0 \mathrm{~b}$ & $0.8 \mathrm{c}$ \\
\hline Chlorhexidine digluconate $^{10}$ & $*$ & $*$ & $*$ & $*$ & $0.6 \mathrm{~b}$ & $1.2 \mathrm{bc}$ & $*$ & $*$ \\
\hline \multirow[t]{2}{*}{ Na dicloroisocyanurate ${ }^{10}$} & $*$ & $*$ & $*$ & $*$ & $*$ & $*$ & $0.4 \mathrm{ab}$ & $1.4 \mathrm{bc}$ \\
\hline & \multicolumn{8}{|c|}{ Incidence of $\operatorname{rot}(\%)$} \\
\hline Pathogen $^{9}$ & $4.9 \mathrm{a}^{7}$ & $19.0 \mathrm{a}$ & $2.1 \mathrm{a}$ & $13.4 \mathrm{a}$ & $18.3 \mathrm{a}$ & $27.5 \mathrm{a}$ & $4.6 \mathrm{a}$ & $13.6 \mathrm{a}$ \\
\hline Iprodione $^{10}$ & $0.7 \mathrm{~b}$ & $3.8 b$ & $0.2 \mathrm{~b}$ & $10.5 \mathrm{a}$ & $3.1 \mathrm{~b}$ & $7.8 b$ & $0.4 b c$ & $3.3 b$ \\
\hline Thiabendazole $^{10}$ & $0.5 b$ & $1.3 b$ & $0.3 b$ & $3.6 b c$ & $1.3 \mathrm{bc}$ & $2.8 \mathrm{~cd}$ & $0.0 \mathrm{c}$ & $0.0 \mathrm{~b}$ \\
\hline Yeast $^{11}$ & $0.0 \mathrm{~b}$ & $1.8 \mathrm{~b}$ & $0.3 b$ & $5.4 \mathrm{~b}$ & $0.6 \mathrm{bc}$ & $1.7 \mathrm{~d}$ & $1.9 \mathrm{bc}$ & $11.4 \mathrm{a}$ \\
\hline Na dichloro-s-triazinetrione ${ }^{10}$ & $*$ & $*$ & $*$ & $*$ & $2.7 \mathrm{bc}$ & $4.2 \mathrm{~cd}$ & $0.6 b c$ & $3.0 \mathrm{~b}$ \\
\hline Sodium hypochlorite ${ }^{10}$ & $*$ & $*$ & $*$ & $*$ & $0.2 \mathrm{~cd}$ & $7.2 \mathrm{bc}$ & $0.0 \mathrm{c}$ & $4.0 \mathrm{~b}$ \\
\hline Chlorhexidine digluconate $^{10}$ & $*$ & $*$ & $*$ & $*$ & $1.3 \mathrm{bc}$ & $2.2 \mathrm{~d}$ & $*$ & $*$ \\
\hline \multirow[t]{2}{*}{$\mathrm{Na}$ dicloroisocyanurate ${ }^{10}$} & $*$ & $*$ & $*$ & $*$ & $*$ & $*$ & $2.3 b$ & $4.4 \mathrm{~b}$ \\
\hline & \multicolumn{8}{|c|}{ Flesh firmness $\left(\mathrm{kg} \mathrm{F} \mathrm{cm}^{-2}\right)$} \\
\hline Pathogen $^{9}$ & $6.7^{7}$ & 6.8 & 7.1 & 6.6 & 8.0 & 7.6 & 7.1 & 6.2 \\
\hline Iprodione $^{10}$ & 6.6 & 6.9 & 6.9 & 6.8 & 7.7 & 7.3 & 7.1 & 6.3 \\
\hline Thiabendazole $^{10}$ & 6.5 & 6.6 & 6.8 & 6.6 & 8.0 & 7.6 & 6.7 & 6.1 \\
\hline Yeast $^{11}$ & 6.8 & 6.5 & 6.7 & 6.5 & 7.8 & 7.4 & 7.0 & 6.3 \\
\hline Na dichloro-s-triazinetrione ${ }^{10}$ & $*$ & $*$ & $*$ & $*$ & 7.9 & 7.4 & 7.1 & 6.0 \\
\hline Na hypochlorite ${ }^{10}$ & $*$ & $*$ & * & * & 7.9 & 8.0 & 6.7 & 5.9 \\
\hline Chlorhexidine digluconate $^{10}$ & $*$ & $*$ & $*$ & $*$ & 7.4 & 7.3 & * & $*$ \\
\hline \multirow[t]{2}{*}{ Na dicloroisocyanurate ${ }^{10}$} & $*$ & $*$ & $*$ & $*$ & $*$ & $*$ & 6.7 & 6.0 \\
\hline & \multicolumn{8}{|c|}{ Total soluble solid content ( ${ }^{\circ}$ Brix) } \\
\hline Pathogen $^{9}$ & $15.6^{7}$ & 15.8 & 13.5 & 14.2 & 15.5 & 15.7 & 13.1 & 13.4 \\
\hline Iprodione $^{10}$ & 15.4 & 15.6 & 14.1 & 14.0 & 15.4 & 15.7 & 14.2 & 14.3 \\
\hline Thiabendazole $^{10}$ & 16.0 & 15.5 & 14.6 & 14.5 & 15.4 & 15.9 & 14.0 & 13.9 \\
\hline Yeast $^{11}$ & 15.4 & 15.4 & 14.0 & 14.3 & 15.5 & 15.8 & 13.9 & 14.1 \\
\hline $\mathrm{Na}$ dichloro-s-triazinetrione ${ }^{10}$ & $*$ & $*$ & $*$ & $*$ & 15.3 & 15.7 & 13.7 & 14.1 \\
\hline Sodium hypochlorite $^{10}$ & * & $*$ & $*$ & $*$ & 15.3 & 15.6 & 14.0 & 14.1 \\
\hline Chlorhexidine digluconate $^{10}$ & $*$ & $*$ & $*$ & $*$ & 15.2 & 15.8 & $*$ & $*$ \\
\hline Na dicloroisocyanurate ${ }^{10}$ & $*$ & $*$ & $*$ & $*$ & $*$ & $*$ & 13.5 & 13.9 \\
\hline
\end{tabular}


